\title{
Isolation and Identification of Indigenous Cellulolytic Bacteria from Sago Pith Waste at Palopo, South Sulawesi, Indonesia
}

\author{
Mamluatul Faizah ${ }^{1 *}$, Tri Ardyati ${ }^{2}$, Suharjono ${ }^{2}$ \\ ${ }^{1}$ Master Program of Biology, Department of Biology, Faculty of Mathematics and Natural Sciences, University of \\ Brawijaya, Malang, Indonesia \\ 2Department of Biology, Faculty of Mathematics and Natural Sciences, University of Brawijaya, Malang, Indonesia
}

\begin{abstract}
Palopo, South Sulawesi, is one of the traditional industrial centers of sago processing. The accumulation of sago pith waste around industrial sites can pollute the environment. Some microorganisms can degrade the cellulose in sago pith waste. This study was aimed to evaluate the indigenous cellulolytic bacteria from sago pith waste as a biodegradation agent. Bacteria were isolated from sago pith waste and grown on a 1\% Carboxyl methyl cellulose (CMC) agar medium. The cellulolytic activity was analyzed semiquantitatively using $1 \%$ Congo red and quantitatively using the 3,5Dinitrosalicylic Acid (DNS) method at $\mathrm{pH}$ variations of 4, 5, and 6 . The potential isolate was identified based on $16 \mathrm{~S}$ rDNA sequence similarity. This study obtained 21 bacterial isolates where six isolates were A1D, A1E, A1I, A1K, A2A, and B1A had the highest cellulolytic index at $0.82-1.13$. Among those six isolates, the A1E isolate had the highest cellulolytic activity, $0.54 \mathrm{U} \cdot \mathrm{mL}^{-1}$ at $\mathrm{pH}$ 6. The isolate A1E was identified as Burkholderia cepacia JCM 2799 with $99.73 \%$ similarity of $16 \mathrm{~S}$ rDNA sequence.
\end{abstract}

Keywords: Burkholderia cepacia, cellulolytic bacteria, cellulase enzyme, sago waste.

\section{INTRODUCTION}

Sago (Metroxylon sago Rott.) is a native plant in Southeast Asia. Indonesia has the largest sago plantation in the world. South Sulawesi, especially Palopo City, is one of the traditional industrial centers of sago processing in Indonesia, which contributes significantly to the production of sago waste. In 2018, the area of sago plantations in South Sulawesi reached 4,383 ha with a productivity of 2,626 tons of sago [1]. Sago trees contain $20-30 \%$ starch and $70-80 \%$ pith [2]. Thus, the sago waste produced annually ranges from $1,838-2,100$ tons.year ${ }^{-1}$.

In general, the sago pith waste in the sago processing industry is not handled properly. It is only allowed to accumulate on the ground that causing acidity in the soil, polluting the environment and causing unpleasant odors [3]. Soil contamination caused by the sago pith waste requires serious attention, so it is important to degrade it by utilizing microorganisms. Sago pith waste contains $20 \%$ of cellulose [4]. Cellulose is a major component of plant cell walls, unbranched linear chains consisting of several thousand glucose units with $\beta-1,4$ glycosidic bonds. Cellulose is insoluble in water and has high mechanical strength, making it difficult to degrade [5].

\footnotetext{
"Correspondence address:

Mamluatul Faizah

Email : mamluatulfaizah7@gmail.com

Address : Dept. Biology, University of Brawijaya, Veteran Malang 65145
}

Cellulolytic bacteria can degrade cellulose by producing extracellular cellulase enzymes. Cellulase is an enzyme that catalyzes the cellulolysis process (hydrolysis of cellulose) to be glucose, cellobiose, and cellooligosaccharides [6]. Cellulase enzymes produced by microorganisms play an important role in the biodegradation of cellulose and lignocellulose wastes to be more simple compounds. The hydrolysis of cellulose into glucose by cellulase enzymes acts synergistically including three enzymes, namely endo- $\beta$-1,4-glucanase, Cellobio-hydrolase, and $\beta$ glucosidase. Endo $\beta$-1,4-glucanase (EG; $E C$ 3.2.1.4) attack amorphous regions and cleave the internal glycosidic bonds. Cellobiohydrolase (CBH; or Exo- $\beta-1,4$-glucanase, $\beta-1,4-D-$ glucancellobiohydrolase, EC 3.2.1.91) attack the nonreducing cellooligosaccharide chain or crystalline regions and produce cellobiose, then the cellobiose will be hydrolyzed into glucose by $\beta$ glucosidase (BG; cellobiase, $\quad \beta$-D-glucoside glucanohydrolase, EC 3.2.1.21) [7].

Several groups of bacteria such as Cellulomonas, Pseudomonas, Thermoactinomycetes, and Bacillus [8], Bacillus pumilis, B. licheniformis, B. cereus, and Pseudomonas aeruginosa showing cellulolytic activity [9]. Meanwhile, Serratia liquefaciens, Acinetobacter iwofii, Bacillus Licheniformis, and Bacillus cereus were reported as indigenous bacteria from sago waste [10]. Therefore, this study is important to obtain bacterial isolates that have potency as biodegradation agents to solve the problem of sago pith waste. 


\section{MATERIAL AND METHOD}

Sago pith waste sampling

Sago pith waste was collected from the traditional industry of sago in Palopo, South Sulawesi at two locations, location A $\left(2^{\circ} 53^{\prime} 34^{\prime \prime} \mathrm{S}\right.$ $\left.120^{\circ} 10^{\prime} 18^{\prime \prime} \mathrm{E}\right)$ and location B (3²'20.20"S $\left.120^{\circ} 12^{\prime} 33.77^{\prime \prime E}\right)$. The sample was taken from a pile of sago pith waste in the bottom, near the ground, and stored in a plastic bag in an isotherm box. The physicochemical parameter that measured including organic matter, $\mathrm{C} / \mathrm{N}$ ratio, and $\mathrm{pH}$ of sago pith waste. The organic matter and $\mathrm{C} / \mathrm{N}$ ratio were analyzed in Soil Laboratory, Faculty of Agriculture, Brawijaya University.

\section{Isolation and Screening of Cellulolytic Bacteria}

Twenty-five grams of sago pith waste was suspended in $225 \mathrm{~mL}$ of $0.85 \% \mathrm{NaCl}$ solution, and we made serial dilution until $10^{-7}$. The aliquot of sample suspension $0.1 \mathrm{~mL}$ was spread on a Petri dish containing $1 \%$ CMC-agar medium and incubated at $30^{\circ} \mathrm{C}$ for 72 hours. The CMC-agar medium (g. $\mathrm{L}^{-1}$ ) consist of CMC 10, Yeast Extract 4, $\mathrm{KH}_{2} \mathrm{PO}_{4}$ 4, $\mathrm{Na}_{2} \mathrm{HPO}_{4} \quad 4, \mathrm{MgSO}_{4} .7 \mathrm{H}_{2} \mathrm{O} \quad 0.2$, $\mathrm{CaCl}_{2} .2 \mathrm{H}_{2} \mathrm{O} 0.001, \mathrm{FeSO}_{4} .7 \mathrm{H}_{2} \mathrm{O} 0.004$, and agar 15 at pH 6 [11].

The bacterial colonies that were grown on the CMC medium were observed and purified. The pure isolates were screened semi-quantitatively for cellulolytic producing enzymes using Congo red. The isolates then cultivate in $20 \mathrm{~mL}$ of $1 \%$ CMC-broth medium as much as $20 \mu \mathrm{L}$ with equal cell density was $10^{7}$ cells. $\mathrm{mL}^{-1}$ was taken and inoculated on blank disc paper and placed onto $1 \% \mathrm{CMC}$-agar medium and incubated at $30^{\circ} \mathrm{C}$ for 72 hours. After incubation was completed, then flooded with $1 \%$ Congo Red solution for 15 minutes and it washed with $1 \mathrm{M} \mathrm{NaCl}$ solution [12]. The cellulolytic index $(\mathrm{Cl})$ was determined with the formula 1.

$C I=\frac{\text { clear zone diameter }- \text { colony diameter }}{\text { colony diameter }}$

\section{Growth Curve and Crude Enzyme Production of Selected Bacteria}

Broth culture of selected bacterial isolates (10\%) were inoculated into $100 \mathrm{~mL}$ of $1 \%$ CMCbroth medium and incubated in a rotary shaker at $30^{\circ} \mathrm{C}, 120 \mathrm{rpm}$ for $72 \mathrm{~h}$. The bacterial culture as much as $5 \mathrm{~mL}$ were taken every $4 \mathrm{~h}$ for 7 days and optical density (OD) was measured using a spectrophotometer at $540 \mathrm{~nm}$ wavelength. The production of crude cellulase of each bacterium was determined at the exponential growth phase. The crude enzyme was obtained by centrifugation of culture medium at $4^{\circ} \mathrm{C}, 10.000$ rpm for 10 minutes. The supernatant was defined as a crude cellulase enzyme [13].

\section{Cellulolytic Activity Assay}

Cellulolytic activity of each selected bacteria was assayed quantitatively by incubated substrate of $1 \% \mathrm{CMC}$ in the $1800 \mu \mathrm{L} 20 \mathrm{mM}$ buffer citrate ( $\mathrm{pH} \mathrm{4,} \mathrm{5,} \mathrm{and} \mathrm{6)} \mathrm{with} 200 \mu \mathrm{L}$ crude enzyme extract at $30^{\circ} \mathrm{C}$ for 30 minutes. The reaction was stopped by added $2 \mathrm{~mL}$ of DNS then boiled in a water bath at $100^{\circ} \mathrm{C}$ for 5 minutes. The sample was cooled at room temperature and its absorbance was measured at $540 \mathrm{~nm}$. One unit of cellulase enzyme activity is defined as the amount of enzyme that releases $1 \mu \mathrm{mol}$ glucose per $\mathrm{mL}$ per minute. The values of the cellulolytic activity were determined based on the glucose standard curve [13].

\section{Identification of Bacteria Based on 16S rDNA}

Bacterial chromosomal DNA was extracted using a Quick-DNA ${ }^{\mathrm{TM}}$ Fungal/Bacterial Miniprep Kit (ZYMO RESEARCH, USA). The 16S rDNA sequence was amplified by Polymerase Chain Reaction (PCR) using universal primer 27f (5'AGAGTTTGATCCTGGCTCAG3') and 1492r (5'GGTTACCTTGTTACGACTT-3') with PCR program: pre-denaturation at $94^{\circ} \mathrm{C}$ for $5 \mathrm{~min}$, followed by denaturation at $94^{\circ} \mathrm{C}$ for $30 \mathrm{~s}$, annealing at $55^{\circ} \mathrm{C}$ for $30 \mathrm{~s}$, and extension at $72^{\circ} \mathrm{C}$ for $30 \mathrm{~s}$ over 35 cycles and a final extension at $72^{\circ} \mathrm{C}$ for $5 \mathrm{~min}$. The amplicon of $16 \mathrm{~S}$ rDNA was confirmed by $1.5 \%$ agarose gel electrophoresis and visualized using a UV transilluminator. An amplicon of 16S rDNA was purified and sequenced in First BASE, Malaysia. The 16S rDNA sequences of bacteria were aligned with reference strains from the GenBank database using the MEGA V.6 program, and the phylogeny tree was constructed and inferred according to the Neighbor-joining algorithm and Tamura-Nei model [14].

\section{Data Analysis}

Semiquantitative data of cellulolytic activity was variance analyzed based on One-Way ANOVA. Meanwhile, quantitative data of cellulolytic activity were analyzed based on TwoWay ANOVA followed by Tukey test using SPSS 16 program.

\section{RESULT AND DISCUSSION \\ Potential Isolates of Cellulolytic Bacteria}

The study of cellulolytic bacteria from the sago pith waste was obtained 21 isolates where 16 isolates from location $A$ and 5 isolates from location $B$. The density of cellulolytic bacteria at 
location A $25 \times 10^{5}$ CFU.g $^{-1}$ was higher than location B $19.3 \times 10^{5}$ CFU.g ${ }^{-1}$. The low bacterial density at location $B$ is due to the lower organic carbon, nitrogen, $\mathrm{C} / \mathrm{N}$ ratio, and organic matter in sago pith waste samples (Table 1). Organic matter plays an important role in microorganism density and $\mathrm{pH}$ [15]. The low $\mathrm{pH}$ in sago pith waste is due to the fermentation activity of microorganisms to form organic acids (acetic acid, pyruvic acid, and lactic acid) [16,17]. Carbon and nitrogen are macromolecules that have structural and functional roles in bacteria's cell components [18]. Based on similar research, the physicochemical parameter of sago pith waste contained $33.01 \%$ C-organic, $1.66 \% \mathrm{~N}$-total, $20 \%$ $\mathrm{C} / \mathrm{N}$ ratio [19], and $\mathrm{pH} 6$ [17].

Table 1. Physicochemical parameter of sago pith waste

\begin{tabular}{lcc}
\hline Parameter & Location A & Location B \\
\hline C-organic (\%) & $38.9 \pm 1.22$ & $31.5 \pm 3.25$ \\
N-total (\%) & $0.2 \pm 0.06$ & $1.2 \pm 0.69$ \\
C/N ratio & $179.7 \pm 37.07$ & $37 \pm 28.69$ \\
Organic matter (\%) & $67.3 \pm 2.10$ & $54.5 \pm 5.62$ \\
$\mathrm{pH}$ & $5.9 \pm 0.66$ & $4.7 \pm 0.35$ \\
\hline
\end{tabular}

Based on the cellulolytic index, there were six potential isolates consist of A1E, A1K, A1D, A2A, $A 11$, and $B 1 A$ with cellulolytic index were 1.13, $0.97,0.93,0.88,0.82$, and 0.82 , respectively (Fig. 1). The clear zone indicates the ability of bacteria to produce cellulase enzymes to hydrolyze cellulose substrates [20]. The similar research from sago waste reported that Serratia liquefaciens, Acinetobacter iwofii, Bacillus licheniformis, and Bacillus cereus had cellulolytic index were 1.019, 2.009, 1.031, and 1.195, respectively [10]. Based on this study, the cellulolytic index of the A1E isolate was similar to the cellulolytic index of Serratia liquefaciens, Bacillus licheniformis, and Bacillus cereus.

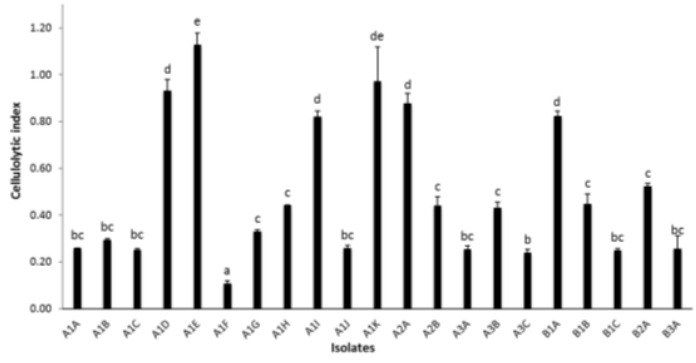

Figure 1. Cellulolytic index of bacteria

\section{Growth Curve of Selected Cellulolytic Bacteria}

The growth curve of six cellulolytic bacterial isolates (Fig. 2), whole isolates were not showed an adaptation phase. The cell density of those isolates was increased significantly at the logarithmic/exponential growth phase from initial incubation until $24 \mathrm{~h}$. In the exponential growth phase, bacteria perform constantly at a maximum growth rate of cell division [13]. The bacterial cells had an optimal production of cellulase at the exponential growth phase [21]. It is due to cellulase as primary metabolites that have an important role in decomposing cellulose to be glucose as the carbon source for bacterial growth [22]. The stationary growth phase of cellulolytic bacteria occurred from $24 \mathrm{~h}$ until $64 \mathrm{~h}$ for $A 1 D, A 1 I, A 2 A$, and $B 1 A$, then followed by the death phase at $72 \mathrm{~h}$, whereas $A 1 \mathrm{E}$ and $\mathrm{A} 1 \mathrm{~K}$ still in the stationary growth phase at $72 \mathrm{~h}$. In the stationary growth phase, there is a balance between the number of live cells and dead cells [23].

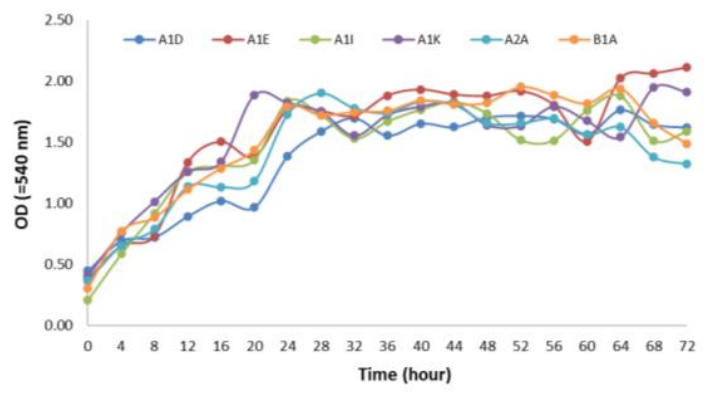

Figure 2. Growth curve of cellulolytic bacteria

Each bacterial isolate with a density of $10^{7}$ cells. $\mathrm{mL}^{-1}$ at exponential growth phase $(24 \mathrm{~h}$ incubation) had the highest potency for the production of cellulase enzymes A similar study showed the exponential growth phase of cellulolytic bacteria occurs at $4-24 \mathrm{~h}$ incubation [13]. Another research was reported that the production of cellulase enzymes at $24 \mathrm{~h}$ incubation [24]. The exponential growth phase was considered at the incubation time of $36 \mathrm{~h}$. Bacterial cultures have a significant cell mass at the exponential phase that can be expected the cellulase enzymes production more quickly [25].

\section{Cellulolytic Activity of Bacterial Isolates}

The $\mathrm{A} 1 \mathrm{E}$ isolate at optimum $\mathrm{pH} 6$ had the highest cellulolytic activity for 0.54 U. $\mathrm{mL}^{-1}$ (Fig. 3). The isolate $A 1 K, A 1 D$, and $A 1$ at optimum $\mathrm{pH} 6$ had a cellulolytic activity for $0.35 \mathrm{U} . \mathrm{mL}^{-1}, 0.27$ U. $\mathrm{mL}^{-1}$, and 0.22 U. $\mathrm{mL}^{-1}$, respectively. While A2A and $\mathrm{B} 1 \mathrm{~A}$ isolates at optimum $\mathrm{pH} 5$ had cellulase activity for 0.31 U.mL ${ }^{-1}$ and 0.33 U. $\mathrm{mL}^{-1}$, respectively. A similar study was reported that Cerenna sp. and Pseudomonas aeruginosa at optimum $\mathrm{pH} 6$ had cellulase activity $0.928 \mathrm{U} \cdot \mathrm{mL}^{-1}$ and 1.554 U. $\mathrm{mL}^{-1}$, respectively [26]. Bacillus subtilis, B. brevis, Paenibacillus sp., and 
Cellulomonas sp. are active at optimum pH 5.5 7 [24]. The Cellulase activity of Citrobacter sp. from pretreated bagasse was optimum at $\mathrm{pH} 6$ [27].

The $\mathrm{pH}$ is a factor that has a significant effect on the stability of enzymatic reaction [28]. The enzymes that are produced from different bacteria allow them to have different optimum $\mathrm{pH}$ for their activity. When the $\mathrm{pH}$ changes, the enzyme's active site, and the substrate can alter because of the ionization. It influences the rate of the binding substrate to the active site of the enzyme [29]. Based on this research, at $\mathrm{pH} 6$ and $\mathrm{pH} \mathrm{5,} \mathrm{the} \mathrm{active} \mathrm{site} \mathrm{of} \mathrm{the} \mathrm{cellulase} \mathrm{can} \mathrm{be}$ ionized optimally. Therefore, its activity can be optimal, as well.

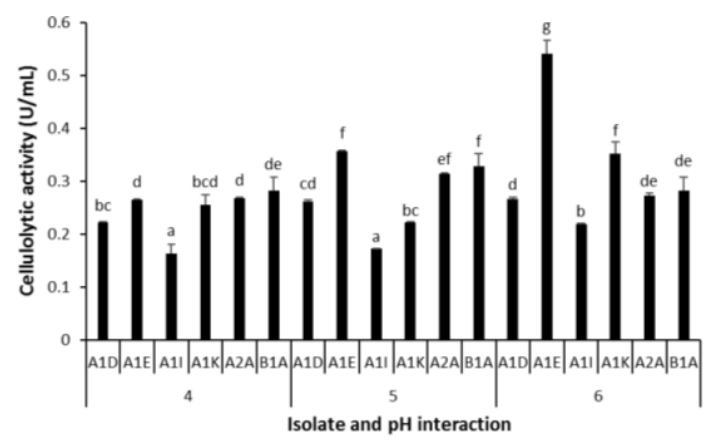

Figure 3. Cellulolytic activity of bacteria at $\mathrm{pH}$ variation

\section{Species of Potential Cellulolytic Bacteria}

Potential cellulolytic bacteria A1E isolate from sago pith waste was identified phylogenitically based on 16S rDNA sequence similarity. Figure 4 showed that the A1E isolate was identified as Burkholderia cepacia JCM 2799 with 99.73\% similarity of 165 rDNA sequence (Fig. 4). Previous studies also reported that Burkholderia cepacia from banana peel waste was potential as a cellulose decomposer with cellulolytic index 1.36 [30].

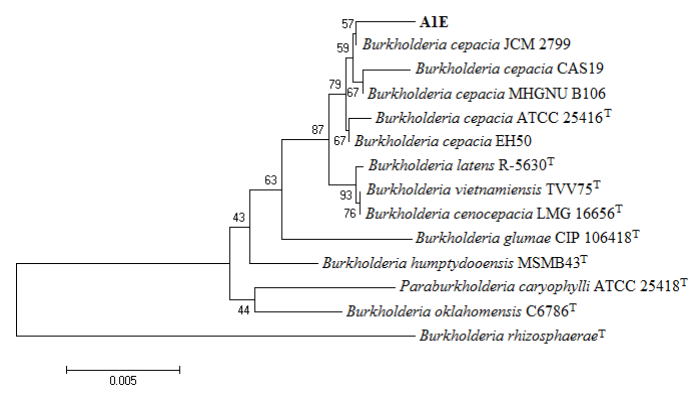

Figure 4. Phylogeny tree that showed relationship of $\mathrm{A} 1 \mathrm{E}$ isolate and reference bacterial strains based on $16 S$ rDNA sequence according Neighbor-joining algorithm
Burkholderia is a genus of lignocellulolytic bacteria [31, 32], and it is known to have cellulolytic activity [33]. Burkholderia cepacia from the soil in Xiling mountain has a cellulolytic activity of $2.76 \mathrm{U} . \mathrm{mL}^{-1}$ at optimum temperature $60^{\circ} \mathrm{C}$ and $\mathrm{pH} 5$ [34]. The different enzyme activity of bacteria can be influenced by the different conditions in the medium such as temperature, $\mathrm{pH}$, carbon source, nitrogen source, enzymes, and substrate concentration [29].

\section{CONCLUSION}

The A1E indigenous isolate of sago pith waste from Palopo, South Sulawesi, had the highest potency as cellulolytic bacteria. The cellulase activity $0.54 \mathrm{U} . \mathrm{mL}^{-1}$ was optimum at $\mathrm{pH}$ 6. The A1E isolate was identified as Burkholderia cepacia JCM 2799 with $99.73 \%$ similarity.

\section{REFERENCES}

[1] Directorate General of Plantations. 2017. Plantation statistic Indonesia. Secretariat Directorate of Plantations. Jakarta.

[2] Yanti, N.A., A. Munir. 2014. Screening bakteri amilolitik dan selulolitik dari limbah sagu. Biowallacea. 1(1). 1-6.

[3] Awg-Adeni, D.S., S. Abd-Aziz., K. Bujang, M.A. Hassan. 2010. Bioconversion of sago residue into value added products. Afr. J. Biotechnol. 9(14). 2016-2021.

[4] Kiat, L.J. 2006. Preparation and characterization of carboxymethyl sago waste and its hydrogel. Master Thesis. Universiti Putra Malaysia. Malaysia.

[5] Omoniyi, O., O.A. Okwa, O.O. Junaid, I.O. Ikuoye, A. Oyebola. 2016. Sustainable solid waste management: isolation of cellulolytic microorganisms from dumpsites in Lagos, Southwest Nigeria. Int. J. Curr. Microbiol. App. Sci. 5(11). 842-853.

[6] Irfan, M., A. Safdar, Q. Syed, M. Nadeem. 2012. Isolation and screening of cellulolytic bacteria from soil and optimization of cellulase production and activity. Turk. J. Biochem. 37(3). 287-293.

[7] Behera, B.C., B.K. Sethi, R.R. Mishra, S.K. Dutta, H.N. Thatoi. 2017. Microbial cellulases - diversity \& biotechnology with reference to mangrove environment: A review. J. Genet. Eng. Biotechnol. 15. 197210.

[8] Lokhande, S., M. Musaddiq. 2015. Isolation of cellulolytic bacterial strains for bioconversion of municipal solid waste. Int. J. Appl. Res. 1(11). 902-905. 
[9] Chaudhary, N., J.I. Qazi, M. Irfan. 2017. Isolation and identification of cellulolytic and ethanologenic bacteria from soil. Iranian J. Sci. Technol.

[10] Hastuti, U.S., P. Yakub, H.N. Khasanah. 2014. Biodiversity of indigenous amylolytic and cellulolytic bacteria in sago waste product at Susupu, North Moluccas. J. Life Sci. 8. 920-924.

[11] Thomas, L., H. Ram, V.P. Singh. 2018. Inducible cellulase production from an organic solvent tolerant Bacillus sp. SV1 and evolutionary divergence of endoglucanase in different species of the genus Bacillus. Braz. J. Microbiol. 49. 429-442.

[12] Rawway, M., S.G. Ali, A.S. Badawy. 2018. Isolation and identification of cellulose degrading bacteria from different sources at assiut governorate (Upper Egypt). J. Eco. Heal. Env. 6(1). 15-24.

[13] Jannah, A., Aulanni'am., T. Ardyati, Suharjono. 2018. Isolation, cellulase activity test and molecular identification of selected cellulolytic bacteria indigenous rice bran. Indones. J. Chem. 18(3). 514- 52.

[14] Potprommanee, L., X.Q. Wang, Y.J. Han, D. Nyobe, Y.P. Peng, Q. Huang, J.Y. Liu, Y.L. Liao, K.L. Chang. 2017. Characterization of a thermophilic cellulase from Geobacillus sp. HTA426, an efficient cellulase-producer on alkali pretreated of lignocellulosic biomass. PLOS ONE. 12(4). 1-16.

[15] Garbeva, P., J.A. van Veen, J.D. van Elas. 2004. Microbial diversity in soil: selection of microbial population by plant and soil type and implications for disease suppressiveness. Annu. Rev. Phytopathol. 42. 243-270.

[16] Indrayati, S., Y.M. Nur, Periadnadi., Nurmiati. 2017. Pemanfaatan ampas sagu (Metroxylon sago Rottboel.) hasil fermentasi Trichoderma harzianum Rifai dan penambahan microflora alami pencernaan ayam broiler dalam pembuatan pakan ayam konsentrat berprobiotik. Jurnal Bibiet. 2(2). 68-74.

[17] Uhi, Harry T. 2007. Peningkatan nilai nutrisi ampas sagu (Metroxylon sp.) melalui biofermentasi. Jurnal IImu Ternak. 7(1). 26-31.

[18] Widadri., W. Mangunwardoyo., H. Ambarsari. 2019. Effect of $\mathrm{C} / \mathrm{N}$ ratio variations on the capability of microbes from Muara Karang river sediment in the production of biogas and identification using VITEK 2. IOP Conf. Series: Earth and Environmental Science. 308. 1-8.

[19] Hammado, N., Budiyono., S. Utomo. 2018. Physicochemical characteristic of sago hampas and sago wastewater in Luwu regency. E3S Web of Conferences. 73. 1-3.

[20] Khotimah, S., Suharjono., T. Ardyati, Y. Nurani. 2020. Isolation and identification of cellulolytic bacteria at fibric, hemic and sapric peat in Teluk Bakung Peatland, Kubu Raya District, Indonesia. Biodiversitas. 21(5). 2103-2112.

[21] Seo, J.K., T.S. Park, I.H. Kwon, M.Y. Piao, C.H. Lee, J.K. Ha. 2013. Characterization of cellulolytic and xylanolytic enzymes of Bacillus licheniformis JK7 isolated from the rumen of a native Korean goat. AsianAustralas J Anim Sci. 26(1). 50-58.

[22] Sanchez, S., A.L. Demain. 2008. Review: metabolic regulation and overproduction of primary metabolites. Microbial Biotechnology. 1(4). 283-319.

[23] Maier, R.M. 2009. Bacterial growth. In: Environmental Microbiology. Elsevier Inc. UK. 37-54.

[24] Meng, F., L. Ma, S. Ji, W. Yang, B. Cao. 2014. Isolation and characterization of Bacillus subtilis strain BY-3, a thermophilic and efficient cellulase-producing bacterium on untreated plant biomass. Lett. Appl. Microbiol. 59(3). 306-312.

[25] Munifah, I., T.C. Sunarti, H.E. Irianto, A. Meryandini. 2015. Biodiversity of cellulolytic bacteria isolated from the solid wastes of agar seaweed processing industry. Squalen Bull. Mar. Fish. Postharvest Biotech. 10(3). 129-139.

[26] Obidi, O.F., O.O Awe, F.O. Okekunjo, M.N. Igwo-ezsikpe. 2018. Studying the cellulolytic activity of microorganisms isolated from stained painted walls with reference to certain factors: a cross sectional study. Int. J. Environ. Sci. 1-10.

[27] Jones, J.A., R.G. Kerr, B.A. Haltli. W.F. Tinto. 2018. Temperature and $\mathrm{pH}$ effect on glucose production from pretreated bagasse by a novel species of Citrobacter and other bacteria. Heliyon. 4. 1-16.

[28] Kiio, I.K., M.F. Jackim, W.B. Munyali, E.K. Muge. 2016. Isolation and characterization of a thermostable cellulase from Bacillus licheniformis strain Vic isolated from geothermal wells in the Kenyan Rift Valley. Open Biotechnol. J. 10. 198-207. 
[29] Robinson, P.K. 2015. Enzymes: principles and biotechnological applications. Essays Biochem. 59. 1-41.

[30] Grevitara, Y.P., B. Rahma, H. Septirangga, I. Dahlia, E. Suarsini. 2018. Isolation and identification of cellulose degrading bacteria from banana peel compost. ElHayah. 7(1). 6-11.

[31] Woo, H.L., T.C. Hazen, B.A. Simmons, K.M. DeAngelis. 2014. Enzyme activities of aerobic lignocellulolytic bacteria isolated from wet tropical forest soils. Syst. Appl. Microbiol. 37.

[32] Akita, H., Z. Kimura, M.Z.M. Yusoff, N. Nakashima, T. Hoshino. 2017. Identification and characterization of Burkholderia multivorans CCA53. BMC Res. Notes. 10(249). 2-6.

[33] Guerrero, E.B., J. Arneodo, R.B. Campanha, P.A. de Oliveira, M.T.V. Labate, T.R. Cataldis, E. Campos, A. Cataldi, C.A. Labate, C.M. Rodrigues, P. Talia. 2015. Prospection and evaluation of (Hemi) cellulolytic enzymes using untreated and pretreated biomasses in two Argentinean Native Termites. PloS ONE. 10(8). 1-23.

[34] Lichun, M., X. Lihui, H. Gang. 2018. Isolation and identification of cellulase-producing bacteria and optimization of their enzymeproducing conditions. China Brewing. 04. 